\title{
Klasifikasi Menggunakan Metode Naïve Bayes: Tingkat Pengaruh Penggunaan Gadget terhadap Kematangan Kecerdasan Emosi Mahasiswa
}

\author{
Umar Zaky*, Ari Prasetyoaji, Ilham Fathullah \\ umar.zaky@staff.uty.ac.id*
}

\section{Universitas Teknologi Yogyakarta - Indonesia}

Diterima: 30 Sep 2020 | Direvisi: 08 Nov - 22 Nov 2020

Disetujui: 27 Des 2020 | Dipublikasi: 28 Des 2020

Program Studi Sistem Informasi, Fakultas Sains dan Teknologi,

Universitas Islam Negeri Raden Fatah Palembang, Indonesia

\begin{abstract}
Gadgets are generally used by individuals to help increase their knowledge, facilitate communication, and also accelerate the development of scientific information. The use of gadgets such as smartphones, laptops, tablets, or iPads has become a habit among students. The students use gadgets for their daily needs. The convenience offered by using gadgets makes students need to be wise in using gadgets. The students can easily search for the lecture materials, take online classes, communicate in a virtual classroom, and see the results of their studies. However, gadgets also have a negative side. Some of the negative effects of the use of gadgets, such as addiction to playing online games, reduced face-to-face interaction, cheating on exams. This article aims to build a classification application for the level of influence of gadget use on the maturity of students' emotional intelligence using the Naïve Bayes method. From this research, the classification application for the level of influence of gadget use on the maturity of student's emotional intelligence using the Naïve Bayes method has been created. The test results of this application show an accuracy of $82 \%$.
\end{abstract}

Keywords: Nä̈ve Bayes Classifier, Gadget, Emotional Intelligence

\section{ABSTRAK}

Gadget pada umumnya dipergunakan individu untuk membantu dalam meningkatkan pengetahuan, mempermudah berkomunikasi dan juga mempercepat perkembangan informasi ilmu pengetahuan. Penggunaan gadget seperti smartphone, laptop, tablet atau ipad sudah menjadi kebiasaan di kalangan mahasiswa. Mahasiswa memanfaatkan gadget untuk keperluan mereka sehari-hari. Kemudahan yang ditawarkan dengan menggunakan gadget membuat mahasiswa perlu secara bijak dalam memanfaatkan gadget. Mahasiswa dapat dengan mudah mencari bahan perkuliahan, mengikuti kelas online, berkomunikasi dalam suatu kelas virtual, hingga melihat hasil studi mereka. Namun, gadget juga memiliki sisi negatif. Beberapa pengaruh negatif dari penggunaan gadget seperti, kecanduan bermain game online, berkurangnya interaksi langsung tatap muka, melakukan kecurangan pada saat ujian. Artikel ini bertujuan untuk membangun aplikasi klasifikasi tingkat pengaruh penggunaan gadget terhadap kematangan kecerdasan emosi mahasiswa menggunakan metode Nä̈ve Bayes. Dari penelitian ini menghasilkan aplikasi klasifikasi tingkat pengaruh penggunaan gadget terhadap kematangan kecerdasan emosi mahasiswa menggunakan metode Naïve Bayes. Hasil pengujian aplikasi ini menunjukkan akurasi sebesar $82 \%$.

Kata Kunci: Naïve Bayes Classifier, Gadget, Kecerdasan Emosi

\section{PENDAHULUAN}

Penggunaan gadget yang semakin meningkat, menjadikan kehidupan manusia menjadi lebih praktis. Setiap saat, gadget bermunculan dengan menyajikan teknologi 
terbaru dan tercanggih untuk memudahkan pekerjaan manusia. Gadget pada umumnya dipergunakan individu untuk membantu dalam meningkatkan pengetahuan, mempermudah berkomunikasi dan juga mempercepat perkembangan informasi ilmu pengetahuan. Gadget digunakan pula karena alasan tuntutan pekerjaan ataupun untuk mempelajari pengetahuan baru yang sedang berkembang. Gadget sudah banyak digunakan di lingkungan perguruan tinggi. Penggunaan gadget seperti smartphone, laptop, tablet atau ipad sudah menjadi kebiasaan di kalangan mahasiswa. Mahasiswa memanfaatkan gadget untuk keperluan mereka sehari-hari. Penggunaan gadget di kalangan mahasiswa dapat bernilai positif dan dapat juga bernilai negatif (Morissan, 2020).

Kemudahan yang ditawarkan dengan menggunakan gadget membuat mahasiswa perlu secara bijak dalam memanfaatkan gadget. Gadget biasa digunakan untuk pendidikan dan hiburan (Gifary \& Kurnia N., 2015). Mahasiswa dapat dengan mudah mencari bahan perkuliahan, mengikuti kelas online, berkomunikasi dalam suatu kelas virtual, hingga melihat hasil studi mereka. Namun, gadget juga memiliki sisi negatif (Doni, 2017). Beberapa pengaruh negatif dari penggunaan gadget seperti, kecanduan bermain game online (Putra P., 2017), berkurangnya interaksi langsung tatap muka (Karuniawan \& Cahyanti, 2013), melakukan kecurangan pada saat ujian (Cahyaningsih et al., 2019). Penggunaan gadget juga semakin tidak terkontrol dengan dukungan jaringan internet (Ginige, 2017) seperti sekarang ini. Selain itu juga, saat ini media online sangat banyak dimanfaatkan (Putra, 2019). Banyaknya media online yang dipergunakan ini juga dapat menambah sisi negatif penggunaan gadget seperti menyebarkan berita bohong (hoax) dan cyberbullying.

Beberapa penelitian terkait penggunaan gadget telah dilakukan oleh para peneliti sebelumnya, seperti pada penelitian (Fitri, 2018; Kuncoro, 2018; Maria, 2013) yang melihat dampak penggunaan smartphone terhadap prestasi akademik, (Musdalifah \& Indriani, 2017) yang menjelaskan dampak penggunaan smartphone terhadap interaksi sosial mahasiswa, dan (Musdalifah \& Indriani, 2017) yang melakukan penelitian mengenai perilaku penggunaan smartphone dengan perubahan budaya pergaulan mahasiswa, serta (Ardyansyah, 2019) yang melihat pengaruh dari penggunaan gadget terhadap motivasi belajar mahasiswa. Dari beberapa penelitian ini, dapat diketahui bahwa gadget memiliki dampak terhadap kehidupan mahasiswa. Kurangnya pemahaman mahasiswa terhadap penggunaan gadget maka dapat mempengaruhi kemampuan mahasiswa dalam mengelola emosi. Hal ini terkandung di dalam kecerdasan emosi seseorang.

Artikel ini bertujuan untuk membangun aplikasi klasifikasi tingkat pengaruh penggunaan gadget terhadap kematangan kecerdasan emosi mahasiswa menggunakan metode Naïve Bayes. Data penggunaan gadget didapatkan dari responden. Daftar pertanyaan dirancang terlebih dahulu sesuai dengan aspek-aspek yang telah ditetapkan di dalam penelitian ini. Menurut (Testiana, 2018), dijelaskan bahwa klasifikasi dengan Naïve Bayes bekerja berdasarkan teori probabilitas yang melihat semua fitur dari data sebagai bukti dalam peluang dan statistik. Selain itu juga metode Naïve Bayes memiliki kinerja yang lebih baik dengan tingkat akurasi yang lebih tinggi (Devita et al., 2018).

\section{METODOLOGI PENELITIAN}

\section{Aspek Penilaian Kematangan Kecerdasan Emosi}

Pada penelitian Usman menyebutkan bahwa kecerdasan emosi merupakan kemampuan mengelola serta mengontrol emosi diri sendiri dan orang lain di sekitarnya (Usman, 2019). Aspek-aspek yang digunakan di dalam penelitian ini mengacu pada penelitian (Hanana, 2018), yaitu: mengenali emosi, mengelola emosi, memotivasi diri 
sendiri, mengenali emosi orang lain, dan membina hubungan. Selanjutnya, aspek-aspek ini dimodifikasi dengan membagi aspek-aspek yang telah ada ke dalam sub aspek yang lebih terperinci lagi. Masing-masing sub aspek akan dirancang pertanyaan yang bersifat positif dan pertanyaan yang bersifat negatif. Pertanyaan-pertanyaan yang telah dirancang tersebut akan digunakan di dalam kuesioner, dapat dilihat secara ringkas pada Tabel 1.

Tabel 1. Aspek Penilaian Kematangan Kecerdasan Emosi

\begin{tabular}{|c|c|c|c|}
\hline \multirow{2}{*}{ Aspek } & \multirow{2}{*}{ Sub Aspek } & \multicolumn{2}{|c|}{ Butir Pertanyaan } \\
\hline & & Positif & Negatif \\
\hline \multirow{2}{*}{$\begin{array}{l}\text { Mengenali } \\
\text { Emosi }\end{array}$} & $\begin{array}{l}\text { Kemampuan untuk mengekspresikan emosi } \\
\text { dengan tepat. }\end{array}$ & 1 & 1 \\
\hline & Kemampuan untu mengenali emosi diri. & 1 & 1 \\
\hline \multirow{2}{*}{$\begin{array}{l}\text { Mengelola } \\
\text { Emosi }\end{array}$} & \multirow{2}{*}{$\begin{array}{l}\text { Kemampuan individu dalam penguasaan diri. } \\
\text { Kemampuan individu untuk menenangkan } \\
\text { kembali. }\end{array}$} & 1 & 1 \\
\hline & & 1 & 1 \\
\hline \multirow{2}{*}{$\begin{array}{l}\text { Memotivasi } \\
\text { diri sendiri }\end{array}$} & Mengerjakan sesuatu untuk mencapai tujuan. & 1 & 1 \\
\hline & Kemampuan untuk mencapai prestasi. & 1 & 1 \\
\hline \multirow{2}{*}{$\begin{array}{l}\text { Mengenali } \\
\text { emosi orang } \\
\text { lain }\end{array}$} & \multirow{2}{*}{$\begin{array}{l}\text { Kemampuan individu untuk berempatik. } \\
\text { Memahami ekpresi orang lain terhadap suatu } \\
\text { peristiwa. }\end{array}$} & 1 & 1 \\
\hline & & 1 & 1 \\
\hline \multirow{2}{*}{$\begin{array}{l}\text { Membina } \\
\text { Hubungan }\end{array}$} & Berinteraksi dengan orang lain. & 1 & 1 \\
\hline & $\begin{array}{l}\text { Menciptakan iklim yang hangat dalam kondisi } \\
\text { berinteraksi. }\end{array}$ & 1 & 1 \\
\hline & Total & 10 & 10 \\
\hline & Total Butir Pertanyaan & \\
\hline
\end{tabular}

\section{Aspek Penilaian Penggunaan Gadget}

Penggunaan gadget di kalangan mahasiswa sudah menjadi kebiasaan. Pengguna gadget yang dimaksud di dalam penelitian ini yaitu pengguna smartphone, laptop, tablet atau ipad di kalangan mahasiswa yang masih berstatus aktif kuliah. Mahasiswa aktif yang dipilih memiliki rentang usia mulai dari 18 hingga 52 tahun. Pengguna gadget di kalangan mahasiswa aktif ini akan sangat bervariasi. Gadget di kalangan mahasiswa, biasanya banyak digunakan untuk keperluan perkuliahan dan komunikasi dengan dosen. Akan tetapi intensitas yang berlebihan dalam penggunaan gadget dapat saja terjadi dan tidak mengenal usia mahasiswa. Oleh karena itu di dalam penelitian ini akan melihat pengaruh penggunaan gadget terhadap kematangan kecerdasan emosi mahasiswa. Di dalam penelitian ini, untuk menggambarkan penggunaan gadget, digunakan tiga aspek yang menjadi acuan dalam penilaian. Dapat dilihat pada Tabel 2.

Tabel 2. Aspek Penilaian Penggunaan Gadget

\begin{tabular}{c} 
Variabel \\
\hline Durasi \\
Konten \\
Tujuan \\
\hline
\end{tabular}

\section{Alur Klasifikasi Metode Naïve Bayes}

Dalam penerapan klasifikasi dengan menggunakan metode Naïve Bayes membutuhkan dataset. Dataset yang baik untuk klasifikasi sebaiknya bervariasi. Di dalam penelitian ini, dataset yang digunakan berasal dari penyebaran kuesioner sesuai 
dengan aspek-aspek yang telah ditentukan sebelumnya. Alur klasifikasi yang digunakan di dalam penelitian ini dapat dilihat pada Gambar 1.

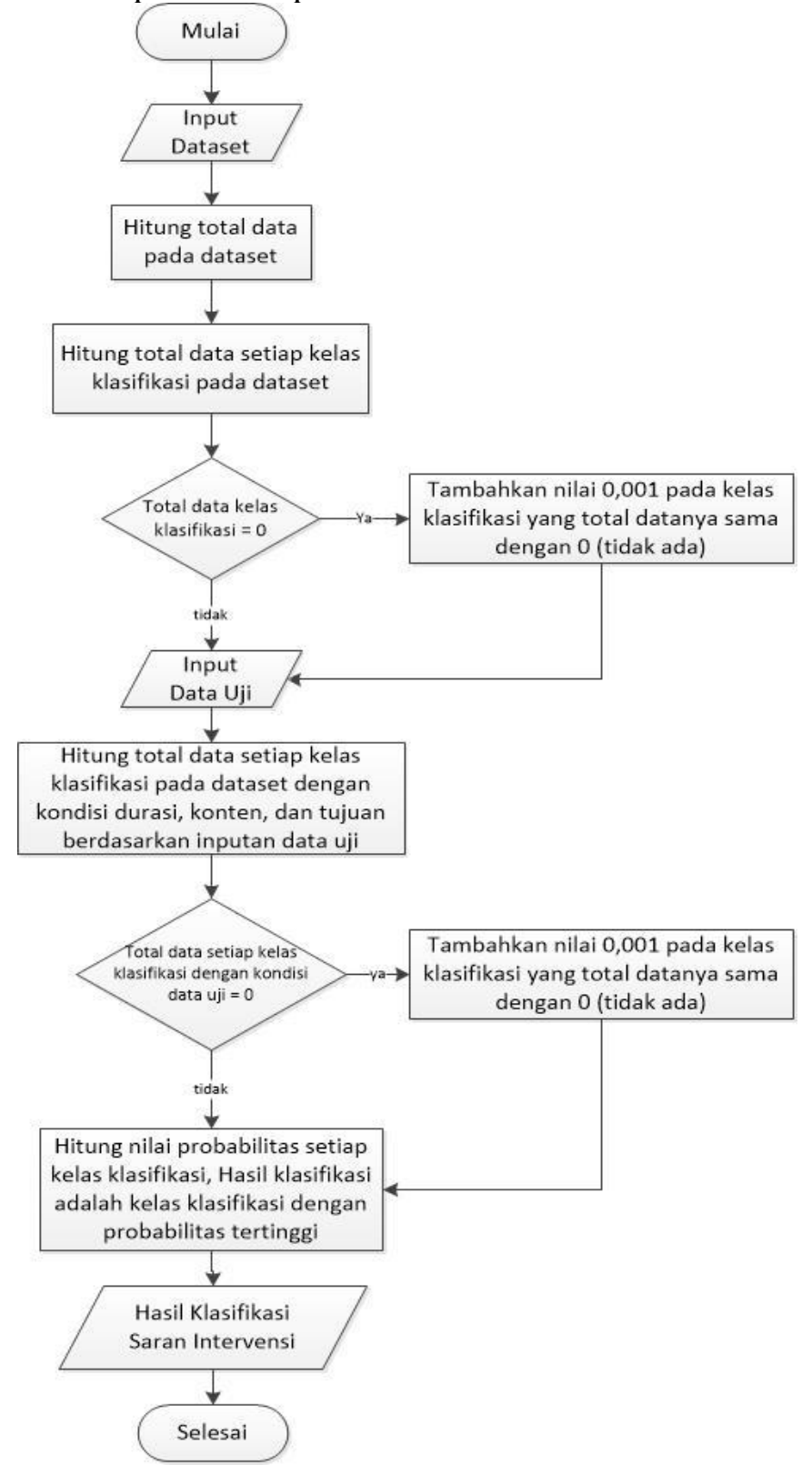

\section{Gambar 1. Alur Proses Klasifikasi dengan Naïve Bayes}

Hasil penyebaran kuesioner akan diklasifikasi ke dalam kelas yang berbeda. Terdapat 5 tingkatan kelas yang digunakan dalam klasifikasi pada penelitian ini. Dapat dilihat pada Tabel 3.

Tabel 3. Kelas Klasifikasi

\begin{tabular}{ccc}
\hline $\begin{array}{c}\text { Rumus Perhitungan } \\
\text { Rentang Skor }\end{array}$ & Rentang Skor & $\begin{array}{c}\text { Tingkatan Pengaruh/ } \\
\text { Kelas Klasifikasi }\end{array}$ \\
\hline $\mathrm{X}<\mathrm{M}-1,5 \mathrm{SD}$ & $\mathrm{X}<40$ & Sangat Rendah \\
$\mathrm{M}-1,5 \mathrm{SD}<\mathrm{X}<\mathrm{M}-0,5 \mathrm{SD}$ & $40<\mathrm{X}<53$ & Rendah \\
$\mathrm{M}-0,5 \mathrm{SD}<\mathrm{X}<\mathrm{M}+0,5 \mathrm{SD}$ & $53<\mathrm{X}<67$ & Sedang \\
$\mathrm{M}+0,5 \mathrm{SD}<\mathrm{X}<\mathrm{M}+1,5 \mathrm{SD}$ & $67<\mathrm{X}<80$ & Tinggi \\
$\mathrm{X}>\mathrm{M}+1,5 \mathrm{SD}$ & $\mathrm{X}>80$ & Sangat Tinggi \\
\hline
\end{tabular}


Dengan ketentuan:

$\mathrm{X}$ : Skor total setiap responden

Skor minimal $(\mathrm{Xmin})=20 \times 1=20$

Skor maksimal (Xmaks) $=20 \times 5=100$

Mean $(M)=(X m a k s+X m i n) / 2=(100+20) / 2=60$

Standar Deviasi (SD) $=($ Xmaks $-\mathrm{Xmin}) / 6=(100-20) / 6=13,33$

Selanjutnya, variabel yang digunakan di dalam penelitian ini untuk klasifikasi dapat dilihat pada Tabel 4.

Tabel 4. Variabel Klasifikasi

\begin{tabular}{c}
\hline Variabel \\
\hline Durasi \\
Konten \\
Tujuan \\
\hline
\end{tabular}

\section{Populasi dan Sampel}

\section{1) Populasi}

Populasi yang digunakan pada penelitian ini adalah mahasiswa aktif pada jenjang pendidikan D1, D3, D4, S1, S2, S3, dan Profesi yang tersebar di provinsi D.I. Yogyakarta. Berdasarkan data statistik (Kemenristekdikti, 2019), didapatkan jumlah populasi mahasiswa di provinsi D.I. Yogyakarta pada tahun 2019 menurut jenjang program dengan status nasional sebesar 398.440 populasi.

2) Sampel

Pada penelitian ini digunakan teknik random sampling, yang mana pengambilan sampel dilakukan secara acak tanpa memandang kriteria tertentu pada anggota populasi. Digunakan rumus slovin dengan margin of error (e) sebesar 5\%. Berikut ini perhitungan sampel dengan menggunakan rumus slovin.

$$
n=\frac{N}{1+N e^{2}}=\frac{398.440}{1+\left(398.440(0,05)^{2}\right)}=\frac{398.440}{997,1}=399,6=400 \text { sampel }
$$

\section{Tahapan Penelitian}

Pada penelitian ini melalui beberapa tahapan yang telah disusun secara sistematis, sehingga penelitian yang dilakukan sesuai dengan target. Tahapan yang dilalui sebagai berikut:

\section{1) Tahap Penentuan sampel}

Pada tahap ini ditentukan sampel untuk mewakili total populasi yang diperoleh berdasarkan data statistik kemenristekdikti tahun 2019 mengenai jumlah populasi mahasiswa di provinsi D.I. Yogyakarta menurut jenjang program dengan status nasional sebesar 398.440 populasi. Dari populasi ini didapatkan sampel sebesar 400 sampel. Jumlah sampel ini merupakan jumlah minimal sampel yang akan dilibatkan sebagai responden di dalam penelitian ini.

2) Tahap Penyusunan dan Uji Instrumen Penelitian

Instrumen pada penelitian ini, disusun berdasarkan aspek-aspek penilaian kematangan kecerdasan emosi pada Tabel 1. Pada tahap ini dilibatkan mahasiswa aktif pengguna gadget untuk menyusun instrumen. Hal ini dilakukan karena target sebaran kuesioner untuk penelitian ini adalah mahasiswa aktif pengguna gadget tersebut. Instrumen penelitian yang telah disusun dengan baik, kemudian disebarkan ke sampel kecil terlebih dahulu yang melibatkan sekitar 60 responden. 
Hasil penyebaran kuesioner akan dilakukan uji validitas dan uji reliabilitas untuk melihat keabsahan dan kehandalan instrumen penelitian.

3) Tahap Pengumpulan Data

Instrumen yang telah baik, kemudian disebarkan ke mahasiswa aktif pengguna gadget di provinsi D.I. Yogyakarta seperti yang telah disebutkan sebelumnya. Pengumpulan data responden dilakukan dengan menggunakan Google Form yang disebarkan secara online. Kuesioner online ini akan dibagikan kepada minimal 400 sampel penelitian.

4) Tahap Analisis Data

Pada tahap ini akan dilakukan analisis data menggunakan metode statistik dengan bantuan aplikasi SPSS. Data yang dianalisis adalah variabel dan subvariabel yang digunakan pada kuisioner.

5) Tahap Membangun Aplikasi

Pada tahapan ini akan dibangun sebuah aplikasi klasifikasi dengan metode Naïve Bayes. Tahapan ini terdiri dari merancang variabel dan subvariabel, merancang alur aplikasi, membangun aplikasi sesuai dengan rancangan yang telah dibuat.

\section{6) Tahap Kesimpulan}

Tahap akhir pada penelitian ini adalah penarikan kesimpulan. Penarikan kesimpulan akan menjawab tujuan penelitian.

\section{HASIL DAN PEMBAHASAN}

\section{Uji Validitas dan Uji Reliabilitas}

Kuesioner disebarkan ke sampel kecil terlebih dahulu yang melibatkan 60 responden untuk dilakukan pengujian validitas dan reliabilitas. Hasil pengujian validitas dapat dilihat pada Tabel 5 . Berdasarkan hasil pengujian validitas, seluruh item pertanyaan yang diujikan valid.

Tabel 5. Hasil Uji Validitas Kuisioner

\begin{tabular}{cccc}
\hline Item Pertanyaan Ke- & r hitung & r tabel & keterangan \\
\hline 1 & 0,376 & 0,254 & valid \\
2 & 0,498 & 0,254 & valid \\
3 & 0,305 & 0,254 & valid \\
4 & 0,325 & 0,254 & valid \\
5 & 0,408 & 0,254 & valid \\
6 & 0,295 & 0,254 & valid \\
7 & 0,512 & 0,254 & valid \\
8 & 0,372 & 0,254 & valid \\
9 & 0,322 & 0,254 & valid \\
10 & 0,534 & 0,254 & valid \\
11 & 0,354 & 0,254 & valid \\
12 & 0,480 & 0,254 & valid \\
13 & 0,348 & 0,254 & valid \\
14 & 0,388 & 0,254 & valid \\
15 & 0,459 & 0,254 & valid \\
16 & 0,365 & 0,254 & valid \\
17 & 0,276 & 0,254 & valid \\
18 & 0,459 & 0,254 & valid \\
19 & 0,465 & 0,254 & valid \\
20 & 0,369 & 0,254 & valid \\
\hline
\end{tabular}


Selanjutnya dilakukan juga uji reliabilitas, hasil pengujian reliabilitas dapat dilihat pada Tabel 6. Berdasarkan hasil pengujian reliabilitas, maka dari nilai Cronbach's Alpha menunjukkan bahwa seluruh item pertanyaan termasuk ke dalam kategori tinggi reliabilitasnya.

Tabel 6. Hasil Uji Reliabilitas Kuisioner

\begin{tabular}{ccc}
\hline $\begin{array}{c}\text { Cronbach's } \\
\text { Alpha }\end{array}$ & $\begin{array}{c}\text { Cronbach's Alpha Based } \\
\text { on Standardized Items }\end{array}$ & N of Items \\
\hline 0,700 & 0,719 & 20 \\
\hline
\end{tabular}

\section{Gambaran Umum Responden}

Gambaran umum responden merupakan visualisasi dari responden yang dilibatkan di dalam penelitian ini. Terdapat tiga karakteristik yang ditampilkan, yaitu: usia, jenis kelamin, dan jenjang pendidikan.

\section{1) Karakteristik Berdasarkan Usia}

Pada Gambar 2 menunjukkan bahwa responden didominasi oleh mahasiswa yang berusia 20 tahun hingga 25 tahun dengan persentase sebesar $70 \%$ (311 mahasiswa). Sedangkan kelompok mahasiswa yang umurnya lebih dari 30 tahun adalah kelompok responden paling sedikit yaitu sebesar $1 \%$ (4 mahasiswa).

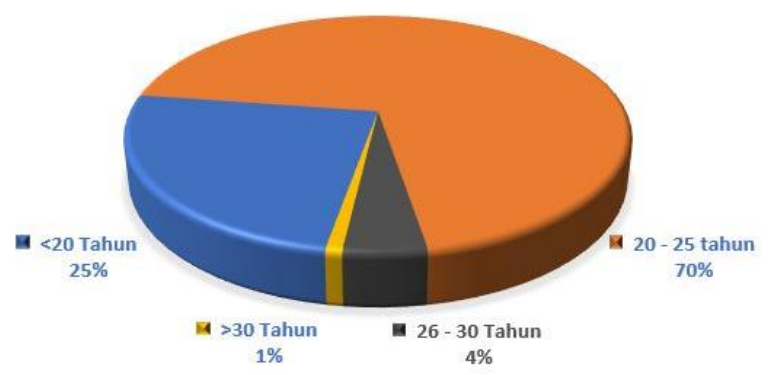

Gambar 2. Responden Berdasarkan Usia

\section{2) Karakteristik Berdasarkan Jenis Kelamin}

Pada Gambar 3 menunjukkan bahwa karakteristik responden berdasarkan jenis kelamin memiliki persentase yang sama yakni sebesar $50 \%$ untuk jenis kelamin perempuan dan $50 \%$ untuk jenis kelamin laki-laki.

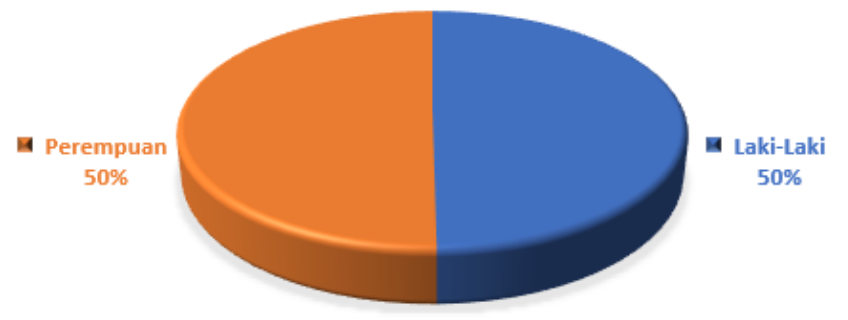

Gambar 3. Responden Berdasarkan Jenis Kelamin

3) Karakteristik Berdasarkan Jenjang Pendidikan

Pada Gambar 4 menunjukkan bahwa responden didominasi oleh mahasiswa yang menempuh jenjang pendidikan S1 dengan persentase sebesar 82\% (366 mahasiswa). Sedangkan kelompok mahasiswa yang menempuh jenjang Pendidikan D1 adalah kelompok responden paling sedikit yakni sebesar 0,004\% (2 mahasiswa). 


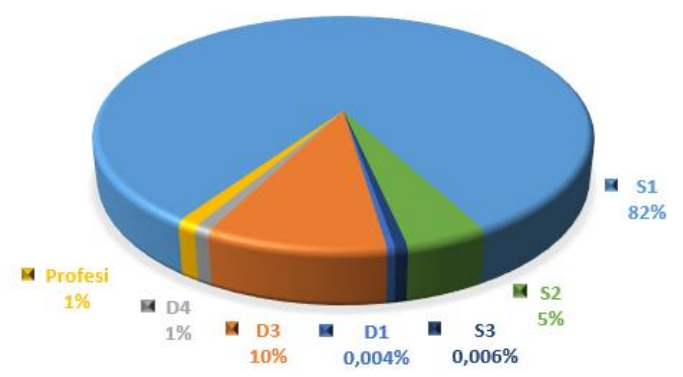

Gambar 4. Responden Berdasarkan Jenjang Pendidikan

\section{Dataset}

Dataset merupakan kumpulan jawaban yang didapatkan dari seluruh responden. Variabel yang digunakan sebagai masukan pada aplikasi yaitu durasi, konten, tujuan. Total dari keseluruhan responden yang mengisi kuesioner dengan lengkap sebesar 444 responden. Hasil sebaran dari dataset dapat dilihat pada Gambar 5.

\begin{tabular}{|c|c|c|c|c|c|c|}
\hline \multirow{2}{*}{ Variabel } & \multirow{2}{*}{ Subvariabel } & \multicolumn{5}{|c|}{ Kelas Klasifikasi } \\
\hline & & Sangat Rendah & Rendah & Sedang & Tinggi & Sangat Tinggi \\
\hline \multirow{5}{*}{ Durasi } & $1-3 \mathrm{Jam}$ & 15 & 30 & 1 & - & - \\
\hline & Kurang dari 1 Jam & 1 & 3 & - & - & - \\
\hline & Lebih dari 3 - 5 Jam & 20 & 57 & 32 & - & - \\
\hline & Lebih dari 5 - 7 Jam & 13 & - & 62 & 48 & - \\
\hline & Lebih dari 7 Jam & 6 & - & 29 & 44 & 83 \\
\hline \multirow{5}{*}{ Konten } & Edukasi & 34 & - & 3 & 2 & - \\
\hline & Game & - & - & 9 & 5 & 9 \\
\hline & Multimedia (musik foto dan video) & 14 & 10 & 84 & 12 & - \\
\hline & Sosial Media & 7 & 68 & 20 & 68 & 74 \\
\hline & Wirausaha (transaksi jual beli) & - & 12 & 8 & 5 & - \\
\hline \multirow{5}{*}{ Tujuan } & Bekerja & 1 & 7 & 14 & 6 & - \\
\hline & Belajar & 51 & 16 & 25 & 28 & - \\
\hline & Hiburan & 2 & 56 & 75 & 46 & 77 \\
\hline & Menambah Teman & - & 2 & - & 6 & 6 \\
\hline & Wirausaha & 1 & 9 & 10 & 6 & - \\
\hline & Total Data Per Kelas Klasifikasi & 55 & 90 & 124 & 92 & 83 \\
\hline
\end{tabular}

\section{Gambar 5. Sebaran Data Penggunaan Gadget pada Dataset}

\section{Pengujian Aplikasi Klasifikasi dengan Metode Naïve Bayes}

Pada penelitian ini, klasifikasi pada aplikasi dengan metode Nä̈ve Bayes menggunakan 3 variabel pengunaan gadget, yaitu: durasi, konten, tujuan. Pada tampilan awal aplikasi, pengguna diberikan 3 pilihan kolom isian. Pengguna bisa memasukkan isian untuk mengetahui tingkat pengaruh pengunaan gadget terhadap kematangan kecerdasan emosi mahasiswa, dapat dilihat pada Gambar 6.

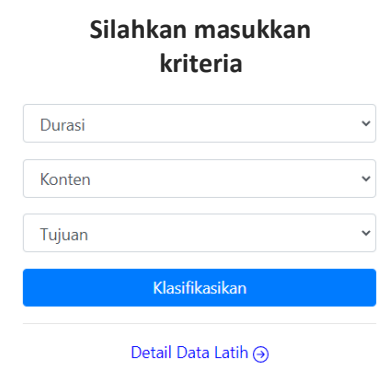

Gambar 6. Tampilan Awal Aplikasi 
Masukan isian data yang dilakukan oleh pengguna akan diproses aplikasi dan diklasifikasi oleh aplikasi menggunakan metode Naïve Bayes. Hasil akhir dari aplikasi dapat dilihat pada Gambar 7.

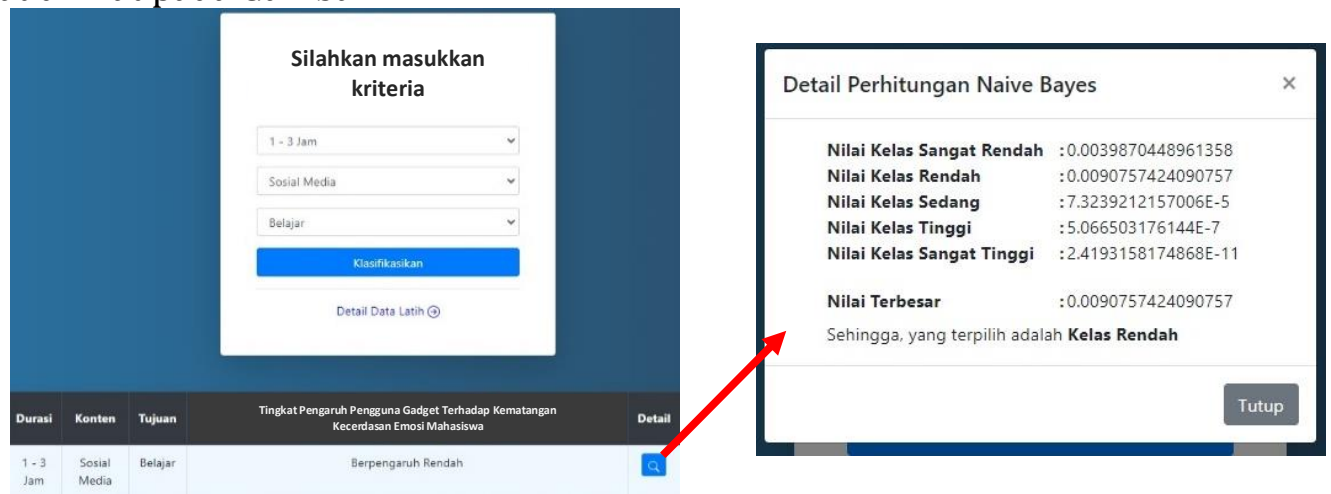

Gambar 7. Tampilan Hasil Klasifikasi dan Detail Perhitungan

Selanjutnya, dilakukan pengujian dataset untuk mengetahui tingkat akurasi yang dihasilkan aplikasi ini sesuai masukan yang diberikan pengguna. Data uji yang digunakan diambil dari $10 \%$ dari dataset masing-masing variabel yang diujikan. Pengambilan $10 \%$ tersebut dilakukan secara acak pada dataset. Hasil pengujian dapat dilihat pada Tabel 7.

Tabel 7. Hasil Pengujian Aplikasi Klasifikasi

\begin{tabular}{ccc}
\hline \multicolumn{2}{c}{ Jumlah } & \multirow{2}{*}{ Akurasi (\%) } \\
\cline { 1 - 2 } Data Uji & Klasifikasi Data Uji Benar & 82 \\
\hline 45 & 37 & 8 \\
\hline
\end{tabular}

Dari hasil pengujian data pada aplikasi menghasilkan akurasi yang tinggi. Hal ini disebabkan sebaran data yang merata pada dataset. Rumus perhitungan akurasi menggunakan persamaan (1).

$$
\text { Akurasi }=\frac{\text { Jumlah_klasifikasi_data_uji_benar }}{j u m l a h_{-} d a t a_{-} u j i} \times 100
$$

\section{KESIMPULAN}

Dari penelitian ini menghasilkan aplikasi klasifikasi tingkat pengaruh penggunaan gadget terhadap kematangan kecerdasan emosi mahasiswa menggunakan metode Naïve Bayes. Aplikasi ini juga telah dilakukan pengujian data yang menghasilkan akurasi yang tinggi sebesar $82 \%$. Hasil sebaran data yang merata pada dataset dapat menghasilkan pengujian data dengan nilai akurasi yang tinggi.

\section{DAFTAR RUJUKAN}

Ardyansyah, S. S. (2019). Pengaruh Penggunaan Gadget Terhadap Motivasi Belajar Bagi Mahasiswa Program Studi Teknik Informatika Itn Malang. Jurnal Valtech, 2(2), 160165. https://ejournal.itn.ac.id/index.php/valtech/article/view/1907

Cahyaningsih, A. A., Ati, N. U., \& Abidin, A. Z. (2019). Gadget dan Mahasiswa (Studi Tentang Dampak Penggunaan Gadget Terhadap Perilaku Mahasiswa di Universitas Brawijaya). Jurnal Respon Publik, 13(3), 21-29.

Devita, R. N., Herwanto, H. W., \& Wibawa, A. P. (2018). Perbandingan Kinerja Metode Naive Bayes dan K-Nearest Neighbor untuk Klasifikasi Artikel Berbahasa indonesia. 
Jurnal Teknologi Informasi dan Ilmu Komputer, 5(4), 427-434. https://doi.org/10.25126/jtiik.201854773

Doni, R. F. (2017). Perilaku Penggunaan Smartphone Pada Kalangan Remaja. Journal Speed Sentra Penelitian Engineering dan Edukasi, 9(2), 16-23.

Fitri, S. A. (2018). Pengaruh Smartphone terhadap Perubahan Prestasi Mahasiswa (Studi pada Mahasiswa Fakultas Dakwah dan Komunikasi Uin Ar-Raniry Jurusan Komunikasi dan Penyiaran Islam) [Universitas Islam Negeri Ar-Raniry]. https://repository.ar-raniry.ac.id/id/eprint/2657/

Gifary, S., \& Kurnia N., I. (2015). Intensitas Penggunaan Smartphone dan Perilaku Komunikasi. Jurnal Sosioteknologi, $\quad 14(2), \quad 170-178$. https://doi.org/10.5614/sostek.itbj.2015.14.2.7

Ginige, P. (2017). Internet Addiction Disorder. In Child and Adolescent Mental Health. InTech. https://doi.org/10.5772/66966

Hanana, N. F. (2018). Pengaruh Self-Esteem dan Kecerdasan Emosi Terhadap Perilaku Prososial. Tazkiya Journal of Psychology, 6(1), 85-100. https://doi.org/10.15408/tazkiya.v6i1.11011

Karuniawan, A., \& Cahyanti, I. Y. (2013). Hubungan antara Academic Stress dengan Smartphone Addiction pada Mahasiswa Pengguna Smartphone. Jurnal Psikologi Klinis dan Kesehatan mental, 2(1), 16-21. http://journal.unair.ac.id/downloadfullpapers-jpkk260c1a8f56full.pdf

Kemenristekdikti. (2019). Statistik Pendidikan Tinggi 2019. In Pusat Data dan Informasi IPTEK Dikti. https://pddikti.kemdikbud.go.id/asset/data/publikasi/Statistik Pendidikan Tinggi Indonesia 2019.pdf

Kuncoro, P. W. (2018). Analisis Dampak Penggunaan Smartphone pada Prestasi Belajar Mahasiswa Universitas Pasundan di Bandung [Universitas Pasundan]. http://repository.unpas.ac.id/37807/

Maria, N. (2013). Pengaruh Penggunaan Smartphone terhadap Nilai Akademik Mahasiswa. ComTech: Computer, Mathematics and Engineering Applications, 4(2), 652-658. https://doi.org/10.21512/comtech.v4i2.2488

Morissan, M. (2020). Hubungan Penggunaan Smartphone dan Kinerja Akademik di Kalangan Mahasiswa. Jurnal Studi Komunikasi (Indonesian Journal of Communications Studies), 4(1), 158. https://doi.org/10.25139/jsk.v4i1.1800

Musdalifah, M., \& Indriani, N. (2017). Pengaruh intensitas penggunaan smartphone terhadap interaksi sosial mahasiswa Politeknik Negeri Samarinda. SNITT-Politeknik Negeri Balikpapan, 2, 144-147.

Putra P., A. S. (2017). Hubungan Kecanduan Bermain Game Online pada Smartphone Terhadap Prestasi Akademik Mahasiswa Angkatan 2013 Fakultas Kedokteran Universitas Lampung. Digital Repository Universitas Lampung.

Putra, R. A. (2019). Tantangan Media Massa Dalam Menghadapi Era Disrupsi Teknologi Informasi. JUSIFO Jurnal Sistem Informasi), 5(1), 1-6. https://doi.org/10.19109/jusifo.v5i1.5003

Testiana, G. (2018). Perancangan Model Prediksi Kelulusan Mahasiswa Tepat Waktu pada UIN Raden Fatah. JUSIFO (Jurnal Sistem Informasi), 4(1), 49-62.

Usman, F. (2019). Pengaruh Kecerdasan Emosi Dan Budaya Organisasi Terhadap Kinerja Melalui Kepuasan Sebagai Variabel Intervening Pada Pegawai Universitas Trunajaya Bontang. Forum Ekonomi, 21(2), 132-142. 